\title{
Communicative Patterns of Imbal Wicara in Ngunduh Mantu Event of Javanese Wedding Tradition
}

\author{
Kumaralalitya Wisnu Pambayun ${ }^{1 *}$ and M. Suryadi ${ }^{2}$ \\ ${ }^{1}$ Faculty of Humanities, Diponegoro University, Semarang, Indonesia \\ ${ }^{2}$ Faculty of Humanities, Diponegoro University, Semarang, Indonesia
}

\begin{abstract}
Indonesia is a country possessing many cultures, one of which is the tradition of wedding ceremonies which differ in each region. In Javanese culture, one of the wedding ceremonies is called ngunduh mantu. Imbal wicara becomes one of the series in that procession. This paper focuses on examining the communication pattern of imbal wicara in ngunduh mantu ceremony, which is a Javanese wedding tradition. It used a qualitative method of communication ethnography with a purposive sampling technique. The results of this study are (1) the communication situation of imbal wicara has two processions, namely pasrah penganten and pasrah tinampi, (2) the communication event of imbal wicara is in the form of giving the bride to the groom's family to be guided wisely, and (3) the communication act of imbal wicara is in the form of gratitude for the two families and hope that their household will always be full of delight. Overcoming Covid-19 through verbal literacy in imbal wicara.
\end{abstract}

\section{Introduction}

It has been more than a year since the Covid-19 pandemic has hit the world, including Indonesia. The World Health Organization (WHO) determined its pandemic status on March 11, 2020, after the first case in Wuhan, China and spread to 110 countries rapidly. Lately, many Indonesian people have dared to hold events to establish and keep up relationships or gather with friends or relatives. In various events held by the community, overcoming the pandemic through verbal literacy can be carried out by appealing to masks, washing hands with running water or using a hand sanitizer, checking body temperature before entering the event venue, and maintaining distance.

Indonesia is an archipelagic country with many cultures and traditions that can affect various aspects of people's lives, including the wedding ceremony. The wedding ceremony is one of the traditional activities that have been passed down from generation to generation.

Every wedding ceremony in Indonesia has different traditions and cultures. Suryakusuma (2008) in Bayu Adi Pratama et al. (2018) [11] explains that traditional Javanese society has a complete procedure for holding a wedding tradition. Procedures in Javanese traditional wedding traditions can usually be divided into three parts: the procedures before

* Corresponding author: kumaralalitya.pmbayun@gmail.com ${ }^{1}$ 
the wedding, the procedures for the day of the wedding (tempukin gawe), and the procedures after the wedding. In the pre-wedding stage, Javanese people usually start the ritual with the procedures of nontoni (establishing relationship or gathering) nglamar (proposing), wangsulan (giving answers), asok tukon (giving money from the prospective groom's family to the bride), srah-srahan (delivering goods as gifts from the prospective groom to the prospective bride), nyantri (the presence of the prospective groom and his family to the prospective bride's house), pasang tarub (setting an additional temporary roof in front of the house), siraman (flower bathing ceremony), and midodareni (a ceremony to wish God's blessings). Next, on the day of the wedding, a boyongan or ngunduh ceremony is usually held (the bride's gathers at the groom's house after the fifth day of marriage). Of the several Javanese traditional wedding procedures, many families or couples want to carry out every procession to make their marriage more sacred.

Ngunduh mantu is one of a series of wedding ceremony in the form of thanksgiving on the groom's party to express the joy of getting a daughter-in-law who has been accepted. They are happy because the family environment is growing. This event is also intended as a tribute to the bride's family (Yadi Kusmayadi, 2018) [6]. Usually, ngunduh mantu is carried out just like a wedding reception. The difference is that it is held by the groom's family as a form of gratitude for their son's marriage.

Ngunduh Ngunduh mantu is a series of wedding ceremonies in the form of thanksgiving at the groom's party to express the joy of getting a daughter-in-law who has been accepted. They are happy because the family environment is growing. This event is also intended as a tribute to the bride's family (Yadi Kusmayadi, 2018) [6]. Usually, ngunduh mantu is carried out just like a wedding reception. The difference is that the groom's family holds it as a form of gratitude for their son's marriage.

Ngunduh mantu is also called boyongan since the bride and groom are escorted to the groom's family together. This ceremony is usually not as complete as the event held at the bride's place, even though it can actually be done in a full manner-depending on the wishes of the groom's family. Ngunduh mantu is held on the fifth day after the wedding reception (Fatkhur Rohman, 2015) [12]. This tradition illustrates that the bride's family submits the bride and groom to the groom's family to be well guided and build a prosperous household.

Imbal wicara comes as one of the various sessions in ngunduh mantu. It is carried out through dialogue - performed during the handover of the bride and groom from the parents of the bride to the parents of the groom (Leswono, 2016) [7]. In imbal wicara procession, usually, those who carry out the handover dialogue are representatives of the bride and groom's families, not members of the nuclear family of both.

There are two prominent processions in it, namely pasrah penganten and pasrah tinampi. Heny Retna Anggraeny et al. (2014) [3] states that the welcoming speech at the wedding consists of two types, namely atur pasrah pinanganten (handover) and atur panampi (acceptance). This welcoming speech uses several languages, namely Indonesian, Javanese (can be ngoko or krama), Arabic, English, and other languages according to the customs wished by the couple's families. This relates to the social context of the orator or other participants. If the ngunduh mantu are Javanese who can also speak Javanese, usually the language used in the speech is Javanese.

A book entitled The Ethnography of Communication explains that ethnography is a field of study related to the description and analysis of culture. This ethnographic study discusses one of them, namely about the unit of analysis.

The unit of analysis is focused on describing and analyzing communication which has an agreement with separate units of several types with the limitations of their communicative activities. According to Hymes (1972) in The Ethnography of Communication described in Saville, Muriel, \& Troike (2003) [14], there are three units that Hymes suggests, namely communicative situation, communicative event, and communicative act. 
A communicative situation is a context in which communication occurs, such as ceremonies, parties, and so on. One situation maintains the consistency of the general configuration of activities - despite the great diversity of communication. Ibrahim (1994) in Helmi Akbar (2010) [2] gives an example: street corners that are busy during the day will have different conditions from street corners during the day.

Communicative event is the basic unit for the same descriptive purpose of communication. A particular event is defined by a unified set of components such as having the same communication intention and purpose, the same communication topic, the same participants, the same variety of languages, and the same rules for interacting. Every time changes in participants, purposes, and topic of communication occur, the communicative event is finished.

The communicative act generally ends with a particular interaction function such as a statement, request, and command. It may be verbal or nonverbal. In conditions of communication, human behaviour that does not carry out any activities is included in conventional communication acts (Ibrahim, 1993 in Helmi Akbar, 2010) [2].

Previous research that has been done related to the topic in this journal was done by Kurnia Husmiwati (2015) [4], focusing on the patterning of the basiacuang tradition communication activities that repeatedly occur in the wedding ceremony of the Kampar Malay community in Riau Province. The method used is a qualitative ethnographic study of communication with subjects selected by purposive sampling. The data collection techniques are observation, interviews, and documentation.

Yulianti et al. (2020) [16] also studied the communication activities in the ritual of opat belas purnama in Kasepuhan Cipinang. The results are (1) the communication situation in the ritual of opat belas purnama goes solemnly and gracefully; (2) the communicative events in the opat belas purnama ritual is the ritual held at imah gede. The participants consist of leader, spell and prayer readers, and several traditional communities. This ritual has the purpose of giving thanks on the moon, praying for ancestors, natives, and possessions or wealth; (3) the communicative act that takes place in the ritual begins with the reading of approval, sermon, and prayer.

Desi Maryanti (2017) [9] conducted a study to determine the ethnography of communication in the thugun mandi tradition in Pelangko Village, Kelayang Sub-district, Indragiri Hulu Regency, Riau Province. The results point out that the thugun mandi tradition carried out by campulsony on every newborn is done at parents' house and attended by the family of the father and mother, as well as the invited people.

Furthermore, Ade Irawan (2018) [5] conducted a study to determine the ethnography of communication in the tradition of question and answer in traditional Malay marriages in Rokan IV Koto Sub-district, Rokan Hulu Regency. The results explain that the communicative situation in the questioning tradition in Malay traditional marriages in Rokan IV Koto Sub-district, Rokan Hulu Regency, is moadatkan situasi tepak sirih tanya mouluokan

Ligga Saputra (2018) [13] also tried to reveal the communicative situation, communicative event, and communicative act in Ngaso Village in the tradition of jalang menjalang ninik mamak kemenakan. The results obtained in this study are the communicative situations of the traditional event of jalang menjalang ninik mamak kemenakan, which is held outdoor, are the multipurpose field of Ngaso Village and the new ninik mamak, tribal parents, community leaders, and nieces and nephews. 


\section{Research Method}

The The method used in this study was qualitative with an ethnographic communication approach. It was selected as it could describe, explain, and build relationships from the categories of data that have been found. The data used was secondary data. Secondary data is data obtained by researchers from existing sources (Harnovinsah, 2018) [1]. The data used in this study are wedding documentation videos that have been collected. Data analysis was carried out by processing, organising, and selecting data into units that are then managed to search for and find communication patterns.

To analyze the qualitative data, the researchers applied qualitative descriptive narrative analysis. According to Bogdan and Tylor, as Lexi Moleong in Asfif Ma'rufah (2014), [8] qualitative descriptive is a method used to analyze data by describing data through written or spoken words from people and behaviours that observed.

In this study, the researchers used a purposive sampling technique, namely, taking samples based on the characteristics of the population that were already known (Notoatmodjo, 2018) [10]. In this case, the groom is the author's cousin. The author attended the ngunduh mantu ceremony. The objects in this study were related to the research focus, namely communicative situation, communicative event, and communicative act that occur in the imbal wicara communication patterns as a session in ngunduh mantu ceremony as a Javanese wedding tradition.

This study proposes to describe and explain what is being studied, namely communicative situation, communicative event, and communicative act that have a communication pattern in imbal wicara session.

\section{Results and Discussion}

\subsection{Communication situation of imbal wicara in ngunduh mantu ceremony}

Ngunduh mantu is an event held by the groom's family as a form of gratitude for the addition of a new family member. In a series of events in ngunduh mantu, there is a dialogue between families represented by their respective family members who are trusted to hand over the bride to the groom's family, called pasrah pengatin, and to receive the bride from the bride's family, called pasrah tinampi.

In imbal wicara procession, the bride and groom came together with their accomplices, namely extended family, close relatives, and neighbours of the bride. After the bride and groom, with their accomplices walked into the building for ngunduh mantu ceremony, the bride, groom, and their attendants stopped in front of the groom's extended family during imbal wicara to carry out a dialogue of pasrah pengantin and pasrah tinampi.

\subsection{Communication event of imbal wicara in ngunduh mantu ceremony}

Imbal Imbal wicara of the ngunduh mantu ceremony is in the form of greetings, prayers, lectures, and conversations carried out by family representatives from both parties. The procession of pasrah pengantin was carried out by the younger brother of the bride's father to represent their family, while the procession pasrah tinampi was carried out by the older brother of the groom's mother. Even though imbal wicara is sacred, the two representatives from both parties might give jokes so that the procession does not become too stiff.

The topic of the dialogue of pasrah penganten in imbal wicara conducted by the bride's uncle contained gratitude from the bride's parents and family to God and the expectations of the bride's parents for the groom's family to accept their daughter as a member and ask for guidance and direction so that they can carry out their duties well. 
The topic of the dialogue of pasrah tinampi was a response to the dialogue from the bride's family conducted by the groom's uncle containing the thanksgiving of the parents and the groom's extended family to God, as well as their happiness for getting a new family member. They would guide and advise the bride according to the wishes of the bride's family and hope that the bride's family is full of peace, prosperity, love and affection.

Participants in the imbal wicara procession were the bride and groom's extended family, their school and office friends, office friends of the couple's parents, and the groom's neighbours and relatives.

In this procession, the dialogue between the two families used Javanese language and Javanese customs because the bride and groom are descendants of Central Java people. This event was held at the wedding building that has been rented by the groom's family, namely the Sudirman Hall building, Jakarta, on March 21, 2021, from 10.00-12.30. Considering that ngunduh mantu ceremony was held during the Covid-19 pandemic, this event was carried out in two sessions, namely at 10.00-11.00 and at 11.30-12.30, so that the place was not full of guests. All participants were asked to carry out the health protocols applied in a strict manner, such as wearing a mask during the event (except when eating or taking photos together), checking body temperature before entering the building, asking to use hand sanitizer or washing hands before entering the wedding building, and prohibiting children under 15 years old from entering the building.

\subsection{Communication act of imbal wicara in ngunduh mantu ceremony}

The The communicative act in the procession of pasrah penganten from the bride's family is a form of gratitude to God from the bride's parents and family who have carried out their obligations, one of which is marrying their daughter to a man who has chosen her. The bride's family hopes for the groom's extended family to accept his daughter as a member of his family with her perfection and imperfection, as well as asking for good guidance and direction so that they can carry out their duties as a wife and prospective mother of the groom. The bride's parents also wish that the household that will be fostered by the bride and groom will be full of happiness, prosperity, love, and mutual supports.

The communicative action in the procession of pasrah tinampi from the groom's family is the thanksgiving of his parents and extended family to God for getting a daughter-in-law. The groom's family wholeheartedly accepts the bride to be a new family member and will guide and advise the bride in a wise way so that she can build a happy, loving, and supportive (sakinah mawaddah wa rahmah) household.

pasrah tinampi have similarities and differences. The similarity lies in the theme of the dialogue carried out by representatives of the two families, namely thanking God and praying for the bride and groom to build a happy and prosperous family. Meanwhile, the difference between the two processions lies in the bride's family handing the bride to the groom's family and the groom's family accepting the bride as a new family member. Based on research conducted by Heny Ratna Anggraeny et al. (2014) [3], the welcoming speech of atur pasrah pinanganten has the same theme as atur panampi. The difference is in the details of the subthemes and main ideas in the atur pasrah pinanganten and atur panampi speeches. Other differences are in terms of the topic of speech "who" given by the orator and the social context in the speech. 


\section{Conclusion}

Based on the research that has been done, the communication pattern in the ethnographic study of communication consists of three parts, namely: (1) the communication situation of imbal wicara in ngunduh mantu ceremony in this study is that there are two processions, namely pasrah penganten and pasrah tinampi, (2) the communication event of imbal wicara in ngunduh mantu ceremony in this study is the submission of the bride to the groom's family to be guided properly and wisely, and (3) the communication act of imbal wicara in ngunduh mantu ceremony in this study is family representatives appointed by each family to hand over and receive the bride providing dialogues of hope so that the bride and groom can build a good, happy, and prosperous household.

\section{References}

1. Ak., Harnovinsah, Dr. Metode Penelitian. (2018)

2. Akbar, H. Makna Ritual Lamaran dan Magang dalam Pernikahan Adat Masyarakat Samin (Studi Etnografi Komunikasi Bernuansa Sejarah Mengenai Ritual Ramalan dan Magang Pernikahan Adat Masyarakat Samin di Kabupaten Bojonegoro). (2010)

3. Anggraeny, HR. dkk. Pola Komunikasi Pidato Sambutan pada Resepsi Pernikahan Adat Jawa-Islam di Kabupaten Pasuruan (Kajian Etnografi Komunikasi). (2014)

4. Husmiwati, K. Pemolaan Komunikasi Tradisi Basiacuang Sebagai Bentuk Kearifan Lokal Dalam Upacara Pernikahan Masyarakat Melayu Kampar Provinsi Riau. (2015)

5. Irawan, A. Etnografi Komunikasi pada Tradisi Sirih Tanya Dalam Adat Pernikahan Masyarakat Melayu di Kecamatan Rokan IV Koto Kabupaten Rokan Hulu. (2020)

6. Kusmayadi, Y. Tradisi Sawer Penganten Sunda di Desa Parigi Kecamatan Parigi Kabupaten Pangandaran. (2018)

7. Leswono. Agama dan Budaya: Studi Tentang Tradisi Perkawinan Berbasis Pitungan pada Masyarakat Islam Desa Taman Prijek Laren Lamongan. (2016)

8. Ma'rufah, A. Dampak Kompetensi Profesional Guru Terhadap Hasil Pembelajaran Pendidikan Agama Islam Siswa SMA Muhammadiyah 3 Gadung Surabaya Tahun Pelajaran 2013/2014. (2014)

9. Maryanti, D. Etnografi Komunikasi dalam Tradisi Thugun Mandi di Desa Pelangko Kecamatan Klayang Kabupaten Indragiri Hulu Provinsi Riau. (2017)

10. Notoatmodjo. Metodologi Penelitian Kesehatan. (2018)

11. Pratama, BA, dkk. Pernikahan Adat Jawa di Desa Nengahan, Kecamatan Bayat, Kabupaten Klaten. (2018)

12. Rohman, F. Makna Filosofi Tradisi Upacara Perkawinan Adat Jawa Kraton Surakarta dan Yogyakarta (Studi Komparasi). (2015)

13. Saputra, L. Pemolaan Komunikasi Tradisi Jalang Menjalang Ninik Mamak Kemenakan: Studi Etnografi Komunikasi pada Masyarakat Desa Ngaso Kecamatan Ujung Batu Kabupaten Rokan Hulu. (2018)

14. Saville, Muriel, Troike. The Etnography of Communication: An Introduction $3^{\text {rd }}$. (2003)

15. Tualaka. Undang-Undang Perkawinan. (2009)

16. Yulianti, dkk. Aktivitas Komunikasi Ritual Opat Belas Purnama: Studi Etnografi Komunikasi di Kasepuhan Cipinang. (2020) 